\title{
Autonomic Ganglion
}

National Cancer Institute

\section{Source}

National Cancer Institute. Autonomic Ganglion. NCI Thesaurus. Code C12720.

A cluster of nerve cell bodies in the peripheral nervous system, which consists of large,

multipolar, motor neurons. There are two types of autonomic gang lia: sympathetic

gang lia lie close to the CNS in sympathetic chain, or in clusters called prevertebral gang lia, and parasympathetic gang lia occur farther from CNS, often in target organs. 